Chicago-Kent College of Law

Scholarly Commons @ IIT Chicago-Kent College of Law

All Faculty Scholarship

Faculty Scholarship

January 2009

\title{
Multiculturalism and the Bretton Woods Institutions
}

\author{
Bartram Brown \\ IIT Chicago-Kent College of Law, bbrown@kentlaw.iit.edu
}

Follow this and additional works at: https://scholarship.kentlaw.iit.edu/fac_schol

Part of the Human Rights Law Commons

\section{Recommended Citation}

Multiculturalism and the Bretton Woods Institutions, in Multiculturalism and International Law: Essays in Honour of Edward McWhinney (Sienho Yee \& Jaques-Yvan Morin eds., Martinus Nijhoff 2009).

This Contribution to Book is brought to you for free and open access by the Faculty Scholarship at Scholarly Commons @ IIT Chicago-Kent College of Law. It has been accepted for inclusion in All Faculty Scholarship by an authorized administrator of Scholarly Commons @ IIT Chicago-Kent College of Law. For more information, please contact jwenger@kentlaw.iit.edu, ebarney@kentlaw.iit.edu. 


\title{
Multiculturalism and the Bretton Woods Institutions
}

\author{
Bartram S. Brown*
}

\section{Introduction}

Multiculturalism has many aspects and broad ramifications. To begin with multiculturalism is an empirical and sociological fact. Multiple cultures exist and these are superimposed upon multiple national states in ever changing ways. These different cultures develop, interact and at times conflict. The multiculturalist view is that mutual respect and recognition of these cultures are essential if they are to work together in a positive way. This is as true in international law and organization as it is in other fields.

The implications of multiculturalism for the World Bank and the International Monetary Fund (IMF), the so-called Bretton Woods institutions, are of particular interest. The Bank and Fund are both multilateral institutions with considerable financial resources as well as unparalleled clout with private financial institutions. They differ in that the basic mission of the Bank is to provide support to developing countries while the IMF was created to stabilize the international monetary system and to monitor the world's currencies.

Both Bank and Fund have enormous power and potential to frustrate, or to promote, the realization of the multicultural ideal. They have inevitably become frequent targets of criticism from those calling for greater multiculturalism in international law and institutions.

The Bretton Woods institutions fall short of the multicultural ideal in a host of ways. They were originally crafted by a monocultural Anglo-American

* Professor of Law and Co-Director, Program in International and Comparative Law, Chicago-Kent College of Law, Illinois Institute of Technology; Member, American Law Institute; Member, Council on Foreign Relations (New York). Thanks to Pauline Dessler for valuable editorial assistance. The views expressed herein are solely the responsibility of the author. 
alliance, and assume liberal economic principles as their basis. This alone makes them vulnerable to multicultural critique. Worse yet, even as they pursue a liberalizing economic agenda, each operates on the basis of a weighted voting system which favors wealthy industrialized countries. Another especially outmoded part of the Bretton Woods formula has been the informal agreement under which the President of the US always nominates the President of the World Bank, while European states have in practice collectively nominated the Managing Director of the IMF.

US President George W. Bush's decision to appoint Paul Wolfowitz as President of the World Bank was a shameless indulgence in unilateral excess. Prior to his appointment Wolfowitz had shown little interest in multilateral institutions, and little background in economic development. Instead he was identified with the failed unilateralist policy of the 2003 US invasion of Iraq. His appointment and subsequent fall from grace at the Bank have exposed the absurd extent of the Western privilege at the Bank and Fund and underlined the need for reforms to limit abuse of that power.

This essay argues that, despite their deficiencies, the Bretton Woods institutions can play an essential role in promoting multiculturalism, human rights and the rule of law, but will be most effective only if they learn to practice and respect these same principles in their own decision-making and other internal practices. Their credibility and ultimate future success depend on it. If the Bretton Woods institutions are to achieve their liberal free-market goals of in the future, US and European leaders can no longer claim the exclusive right to determine who will lead them.

After this introduction, Part II of this paper examines the concepts of diversity and of multiculturalism; Part III introduces the Bretton Woods Institutions and the related issues of multiculturalism; Part IV considers the interplay of law, politics and multiculturalism at the World Bank and IMF; and Part $\mathrm{V}$ formulates a few brief conclusions.

\section{Multiculturalism and Diversity}

Defining multiculturalism can be difficult since the term is used variously to refer to diversity as a de facto demographic situation, to the normative ideals said to 
follow from that situation, or to programmatic policy responses to it. ${ }^{1}$ Multiculturalism gained prominence as a phenomenon at the national level within countries with diverse multicultural populations. It has been described as "a democratic policy response for coping with cultural and social diversity in society". ${ }^{2}$ Faced with the growth of highly diverse immigration within the framework of English/French/Native American linguistic and cultural divides, the Government of Canada has lead the way. ${ }^{3}$ Under the 1988 Canadian Multiculturalism Act it is the policy of that Government "to recognize that multiculturalism is a fundamental characteristic of the Canadian heritage and identity" ${ }^{4}$ and to "encourage and assist the social, cultural, economic and political institutions of Canada to be both respectful and inclusive of Canada's multicultural character". ${ }^{5}$

The thrust of these policies is to recognize and validate the different cultural identities of the groups within Canada. The traditional model of

1 According to a study published by UNESCO " $[\mathrm{t}]$ hree interrelated, but nevertheless distinctive, referents of 'multiculturalism' and its related adjective 'multicultural' which can be distinguished in public debate and discussion are: the demographicdescriptive, the ideological-normative and the programmatic-political." Christine Inglis, Multiculturalism: New Policy Responses to Diversity, MOST Policy Papers N4, UNESCO, 1996, at 16. (http://unesdoc.unesco.org/images/0010/001055/ 105582e.pdf, viewed June 25, 2007).

2 Id. at 6

3 Canadian scholars have likewise lead the way in developing the concept of multiculturalism. See, e.g. Charles Taylor, whose ideas are the focus, infra, notes 6 to 15 and the accompanying text, and Edward McWhinney, who has applied the concept to international law in particular in a long series of thoughtful studies. See, Edward McWhinney, The World Court and the Contemporary International LawMaking Process, Sijthoff \& Norodhoff (1979); Edward McWhinney, Conflict and Compromise, International Law and World Order in a Revolutionary Age, New York (1981); Edward McWhinney, Western and Non-Western Legal Cultures and the International Court of Justice, in: Festschrift: A Celebration of the Scholarship and Teaching of Gray L. Dorsey, 65 Wash. U. L.Q. 873 (1987); and Edward McWhinney, Judge Manfred Lachs, and Judicial Law Making, Opinions of the International Court of Justice, 1967-1993, Kluwer (1995).

4 Canada's policy is that multiculturalism is "an invaluable resource in the shaping of Canada's future." See, the Canadian Multiculturalism Act, R.S., 1985, c. 24 (4th Supp.), [C-18.7], An Act for the preservation and enhancement of multiculturalism in Canada, [1988, c. 31, assented to 21st July, 1988], Article 3(b).

5 Id. Article 3(f). 
liberalism abhors any such official recognition or distinction.

\section{II.A. Multiculturalism and the Politics of Recognition: A Critique of Liberalism's Politics of Equal Dignity}

Charles Taylor, in his essay on the Politics of Recognition, ${ }^{6}$ notes that a "politics of equal dignity" has emerged in Western thought based in part on the ideas of Rousseau and Kant. ${ }^{7}$ It values the notion of equal treatment for all "based on the idea that all humans are equally worthy of respect", 8 and that there are "universal, difference blind principles". 9 Taylor then formulates what is essentially a multicultural critique of this classical liberalism. He stresses that a "crucial feature of human life is its fundamentally dialogical character", ${ }^{10}$ and argues that individuals can only develop and define their identity through dialogue with others. ${ }^{11}$ From this perspective he concludes that " $[t]$ he supposedly fair and difference-blind society is not only inhuman ... but also, in a subtle and unconscious way, itself quite discriminatory". ${ }^{12}$ In his view, recognition is so fundamental to identity that nonrecognition or misrecognition of a group can inflict serious harm. ${ }^{13}$

6 Charles Taylor, The Politics of Recognition, in Charles Taylor et al, edited and introduced by Amy Gutman, Multiculturalism and the "politics of recognition," Princeton University Press (1994) at 25-73 [hereinafter The Politics of Recognition].

7 Taylor notes that " $[\mathrm{t}]$ he politics of equal dignity has emerged in Western civilization Western civilization" with the ideas of Rousseau and Kant as early exponents and standard bearers. The Politics of Recognition, supra note 6 at 44 .

8 Id. at 41.

$9 \quad$ Id. at 43 .

10 Id. at at 32 .

11 "We become full human agents, capable of understanding ourselves and, and hence of defining our identity ... through interaction with others who matter to us." The Politics of Recognition, supra note 6 at 32.

12 Id. at 43.

13 "The thesis is that our identity is partly shaped by recognition or its absence, often by the misrepresentation of others, and so a person or group of people can suffer real damage, real distortion, if the people or society around them mirror back to them a confining or demeaning or contemptible picture of themselves. Nonrecognition or misrecognition can inflict harm, can be a form of oppression, imprisoning someone in a false, distorted, and reduced mode of being." The Politics of Recognition, supra note 6 at 25 . 
Can these two notions, the liberal politics of equal dignity and Taylor's politics of the recognition of difference, be reconciled? Taylor himself does not argue for the abandonment of liberalism, but he does endorse the idea of a new variant of liberalism more open to different cultural perspectives and to collective rights. ${ }^{14}$

Taylor's critique of liberalism is telling in many respects, but he goes too far in predicting that the so-called "rigidities of procedural liberalism may rapidly become impractical in tomorrow's world." 15 Rigidities have a way of becoming impractical, but procedural liberalism need not be rigid. When fairly applied to all states and parties, and with recognition of cultural differences where appropriate, procedural liberalism is the best hope for reconciling multiculturalism with respect for the rule of law at the international level. It is important not to throw out the baby of procedural liberalism and the rule of law, with the bath water of traditional liberalism's culturally blind and therefore implicitly western-biased approach. Of course the rule of law itself must to some extent develop with the times. ${ }^{16}$

In any case multiculturalism is much more than a mere critique of liberalism. To its adherents it is powerful normative principle in its own right. The trend towards greater recognition of multiculturalism's potential for good has been fueled by the development of multicultural values and even of a multicultural ideal. Broadly speaking, multiculturalism values the diversity of cultures and dialogue between them over more insular, monocultural, western, or unilateral attitudes and approaches, and recognizes that internal diversity can

14 "There is a form of the politics respect, as enshrined in a liberalism of rights, that is inhospitable to difference, because (a) it insists on uniform application of the rules defining these rights, without exception, and (b) it is suspicious of collective goals. ... Fortunately, however, there are other models of liberal society that take a different line on (a) and (b)." The Politics of Recognition, supra note 6, at 61.

15 Id. at 61.

16 Edward McWhinney has aptly noted that "the Rule of Law need not be another convenient synonym for perpetuating the political-legal status quo of yesterday, and ... the role of the lawyer and of the judge today consists not merely of mechanically restating the old law but also of assuming responsibility for imaginatively up-dating or re-writing it to correspond with new societal conditions and demands." Edward McWhinney, Western and Non-Western Legal Cultures, supra note 3, at 873, 878-79 (1987). 
impart strength, innovation and growth to a society. ${ }^{17}$

A key rationale for the policy of multiculturalism is recognition of the inherent value of dialogue with "the other". Diversity dialogue can fuel the internal development of the state and its economy. Socrates reportedly said that "the unexamined life is not worth living" and pursuing this foundational "Western" ideal he asked difficult questions about Athenian society for which "crime" he was ultimately sentenced to death. ${ }^{18}$ It is in the spirit of Socrates that multiculturalism stresses the value of learning through an inter-cultural dialogue. ${ }^{19}$ The coincidence of different cultures and peoples in one state can bring to it more varied insights and capabilities which can be especially valuable when dealing with the outside world.

\section{II.B. Critiques of Multiculturalism}

Even some proponents of multiculturalism recognize that it should be implemented with caution. Multiculturalism could potentially disadvantage the rights of individuals within the minority by reducing them to mere members of a recognized group. Respect for difference should not become a license for ingroup subordination. ${ }^{20}$

A more fundamental external critique of multiculturalism challenges the very idea of adopting policies based on cultural differences. Some are concerned that cultural recognition might come at the expense of other values, such as the

17 Canadian Multiculturalism Act, supra note 4, Article 3(b).

18 The charge, according to Plato was " $[\mathrm{t}]$ hat Socrates is a doer of evil, and corrupter of the youth, and he does not believe in the gods of the state, and has other new divinities of his own." See, Plato, Apology, Benjamin Jowett trans. (1942) (The Internet Classics Archive, http://classics.mit.edu/Plato/ apology.html (last viewed June 28, 2007)).

19 "A multicultural curriculum works very well in fulfilling the traditional goals of education in philosophy. It can assist the teacher as Socratic 'midwife' and 'gadfly' in delivering students of their narrow and uncritical opinions and awakening them to a world of intellectual diversity." Carol J. Nicholson, Three Views of Philosophy and Multiculturalism: Searle, Rorty, and Taylor, Encyclopedia of Philosophy of Education, http://www.ffst.hr/ENCYCLOPAEDIA/jcarol.htm (last viewed June 27, 2007).

20 Ayalet Sachar, Two Critiques of Multiculturalism, 23 Cardozo L. Rev. 253, 257 (2001). 
neutrality of public institutions, economic redistribution or progress towards equality of the sexes. ${ }^{21}$ As discussed above, multiculturalism would seem at the very least to imply some derogation from the principle of equal treatment.

A moderate policy of multiculturalism can answer such concerns by balancing multiculturalism and equal treatment. The Constitution of Canada provides that every individual is equal before and under the law and has the right to the equal protection, but also allows for special programs to advance disadvantaged minorities ${ }^{22}$ and therefore Canada must moderate its approach to multiculturalism. The Canadian Multiculturalism Act contains multiple reaffirmations that citizens in Canada should remain legally equality before the law. ${ }^{23}$ It balances these two interests in calling for Canada "to ensure that all individuals receive equal treatment and equal protection under the law, while respecting and valuing their diversity". ${ }^{24}$

In general critics of multiculturalism argue that it will cause much greater problems than those it is intended to address. ${ }^{25}$ Some even depict it as a threat to freedom, progress, reason and science. ${ }^{26}$ In their view the very notion of

21 See, e.g., Ayelet Shachar, Multicultural Jurisdictions: Cultural Differences and Women's Rights (Cambridge Univ. Press, 2001).

22 Under the heading of "Equality Rights" Section 15 of the Canadian Charter of Rights and Freedoms states:

(1) Every individual is equal before and under the law and has the right to the equal protection and equal benefit of the law without discrimination and, in particular, without discrimination based on race, national or ethnic origin, colour, religion, sex, age or mental or physical disability.

(2) Subsection (1) does not preclude any law, program or activity that has as its object the amelioration of conditions of disadvantaged individuals or groups including those that are disadvantaged because of race, national or ethnic origin, colour, religion, sex, age or mental or physical disability.

23 Canadian Multiculturalism Act, supra note 4, calls for it "to ensure that all individuals receive equal treatment and equal protection under the law, while respecting and valuing their diversity." Articles 3(1)(e). See also Preambular paragraphs 1, 5, 6, and 7, and Article 3(2)(a).

24 Canadian Multiculturalism Act, supra note 4, article 3(2)(b) mandates "policies, programs and practices that enhance the ability of individuals and communities of all origins to contribute to the continuing evolution of Canada".

25 See, Ayelet Shachar, Two Critiques of Multiculturalism, 23 Cardozo L. Rev. 253, (2001) at 257-273.

26 As the Ayn Rand Institute puts it:

Multiculturalism seeks to obliterate the value of a free, industrialized civilization 
multiculturalism denies the standards of objectivity and truth which are the foundation of Western civilization 27 and the widespread acceptance of multiculturalism would therefore lead to barbarism. ${ }^{28}$ One author who does not endorse multiculturalism, speaks of objectivity as the search for "the widest possible intersubjective agreement". ${ }^{29} \mathrm{It}$ is true that at one extreme, the assumption that all cultural values are equal could lead to an empty and valueless moral and cultural relativism. Multiculturalism recognizes that "all should enjoy the presumption that their traditional culture has value" but it does not assume that all cultures are of equal value..$^{30}$

\section{Multiculturalism \& the Bretton Woods Institutions}

The discussion thus far has focused upon multiculturalism within a national society. International society is characterized by greater diversity and cultural pluralism than can be found in most national societies. At this level the need for multicultural dialogue is compelling, and addressing multiculturalism in

(which today exists in the West and elsewhere), by declaring that such a civilization is no better than primitive tribalism.

We are opposed to this destructive doctrine. We hold that moral judgment is essential to life. The ideas and values that animate a particular culture can and should be judged objectively. A culture that values freedom, progress, reason and science, for instance, is good; one that values oppression, stagnation, mysticism, and ignorance is not."

Website of The Ayn Rand Institute: (http:://www.aynrand.org/site/ PageServer?pagename=media_topic_multiculturalim), last accessed June 15, 2007.

27 John Searle, "The Storm over the University," in Debating P.C. Paul Berman, ed. (New York: Dell, 1992) at 112.

28 Taylor acknowledges that in the view of multiculturalism critic Roger Kimball " $t]$ he multiculturalists notwithstanding, the choice facing us today is not between a "repressive" Western culture and a multicultural paradise, but between culture and barbarism." The Politics of Recognition, supra note 6 at 72, citing Roger Kimball, Tenured Radicals, New Criterion, January 1991 at 13.

29 Richard Rorty, Does Academic Freedom Have Philosophical Presuppositions: Academic Freedom and the Future of the University, Academe (Nov.-Dec. 1994) at 52.

30 "It makes sense as a matter of right that we approach the study of certain cultures with a presumption of their value ... But it can't make sense to demand as a matter of right that we come up with a final concluding judgment that their value is great, or equal to others." The Politics of Recognition, supra note 6 at 68-70. 
international norms and institutions ${ }^{31}$ can be an especially difficult and delicate challenge.

If, as Taylor argues, individuals and groups within the State can only develop and define their identity through dialogue with others, ${ }^{32}$ the same may also be true of States which can also learn from and influence each other in a global dialogue. This dialogical character is a crucial aspect of each State and of each culture's ability to achieve individuality and is not antithetical to it. What then might be the implications for the Bretton Woods institutions of this broader global vision of multiculturalism?

\section{III.A. Some Background on Bretton Woods}

The Bretton Woods Institutions were a post-World War II Anglo-American project. The period between the two World Wars had been plagued by protectionist high tariffs, exchange rate manipulations, and other economic policies reflecting a narrowly nationalistic and unilateral perspective. These policies had contributed to global economic stagnation by choking off international trade. Recalling the international economic chaos which had preceded the war, the leading economic powers of the time decided to construct a postwar system of international economic organizations which would build a liberal capitalist economic order.

The architects of the Bretton Woods system were influential UK economist John Maynard Keynes and Harry Dexter White of the US Treasury. They brought their governments into agreement on a shared vision of a liberal economic order via more open international trade and a more stable and predictable international monetary system. They attempted to embed this liberal economic vision into the text of the treaties establishing the IMF and the World Bank.

These treaties created powerful and well-funded institutions dedicated to realizing this vision. Each provided for more wealthy or prosperous members to provide the resources which less prosperous and/or developing country

31 As UNESCO notes, "[t]he close parallels between [the] ideological-normative usage of multiculturalism and the United Nations' views on cultural diversity are clear." Christine Inglis, Multiculturalism: New Policy Responses to Diversity, MOST Policy Papers $\mathrm{N}^{\circ} 4$, UNESCO, 1996, at 17. 
members can draw upon, often subject to economic policy conditions. A weighted voting system is part of the price of developing countries pay for access to resources. Together these resources, and this decision-making system, give the Bretton Woods institutions great power over borrower countries.

\section{III.B. The Roles of the IMF and World Bank}

The IMF was intended to be a major pillar of the international economic order, maintaining exchange rate stability, helping its members to deal with short-term balance of payments disequilibria and, in general, establishing a reliable international payments system. The original Bretton Woods fixed exchange rate system completely collapsed in 1973, leaving the IMF in search of a new mission. In adapting to the developing country debt crisis of the 1980s, the IMF found a new niche as the designated advisor to heavily indebted developing countries. On the surface, the Fund's two major activities remain the same: surveillance of national economic policies and providing financial support for adjustment programs when necessary. Now, however, the Fund's advice concerns not only fiscal policy but also banking, competition policy and a broad range of economic policy matters, including governance. ${ }^{33}$ That advice is supposed to be based on the principles of transparency, simplicity, accountability and fairness, which are essential aspects of good governance. ${ }^{34}$ Until recently, ${ }^{35}$ heavily indebted countries generally had little choice but to accept the Fund's austere policy directives.

Fund surveillance is facilitated by the extensive economic information that members are required to divulge to the Fund. Every year or so, pursuant to Article IV of the IMF's Articles of Agreement, the IMF sends a staff team to visit each member country to hold bilateral discussions. The team visits the country to collect economic and financial information and to discuss with national officials the country's economic developments and policies. After

32 The Politics of Recognition, supra note 6 at 32.

33 Robert Graham, Thirteen Years of Change Take Toll on IMF Chief: The Camdessus Years, Financial Times (London) (10 Nov. 1999), 16.

34 See, The Role of the IMF in Governance Issues: Guidance Note (Approved by the IMF Executive Board, 25 July 1997), paragraph 13.

35 See the discussion of Argentina's alternate approach to getting out of debt, infra. notes 68 to 71 and the accompanying text. 
returning to headquarters, the staff prepares a report which is used by the Executive Board as the basis of discussion.

The basic financial resource of the IMF consists of funds from member states, each of which is required to contribute according to a "quota" reflecting the size and strength of its economy. Members are entitled to draw freely upon a first "reserve tranche" of these resources representing their contribution in gold and convertible currencies in excess of this quota. The Fund allows member countries to draw upon additional "credit tranches" of its resources only if they comply with IMF "conditionality," making financing available to debtors only if they promise to comply with IMF-determined conditions concerning their national economic policies and performance. After initial approval, the Fund continues to act as a sort of international financial policeman, monitoring compliance with the promises it has exacted from debtor countries and giving a creditworthiness green light to the international financial community. ${ }^{36}$ Supplementing the basic financial support it makes available to its members, the Fund has developed an array of special "facilities" in response to the persistent economic problems of debtor countries.

In 1945, many countries did not share the enthusiasm of the US and the UK for an IMF to support monetary and financial discipline. Creation of the International Bank for Reconstruction and Development (IBRD), the third pillar of international economic cooperation, broadened the appeal of the proposed system of international financial institutions by offering something concrete to the economically disadvantaged regions of the world. The IBRD was established in 1945 to finance the reconstruction of countries devastated by World War II and the development of more traditionally impoverished areas of the world. The Marshall Plan, introduced in June of 1947, eventually assumed the burden of financing reconstruction in Europe leaving the Bank free to devote its resources to the development task. Today, the IBRD is the central institution in what is known as the World Bank Group.

The Bank's role goes beyond providing development financing, since it has always provided borrowers with advice on development as well. Since there is a fine line between giving advice on development and giving general advice on economic policy, the Bank now shares with the IMF responsibility for inducing

36 For an early analysis, see E. Robichek, The International Monetary Fund: An Arbiter in the Debt Restructuring Process, 23 Columbia JTL (1984), 143. 
debtor countries to make needed macroeconomic reforms.

\section{III.C. Liberal Aspects of the Bank and Fund}

Liberalism is based on the idea that every individual has natural rights including life, liberty and the pursuit of happiness. ${ }^{37}$ As rightly understood, it implies the search for success in the form of truth, justice and understanding. At its best, liberalism demands that we seek effective, workable solutions for problems that are both practically possible in a management sense and consistent with fundamental values such as human rights. Most liberal values are known to other non-liberal, traditions as well, and indeed within the liberal tradition it is often assumed, rightly or wrongly, that its core values are universal.

As noted above, the Bank and Fund were created to promote the liberal economic goal of economic globalization based on open markets. The Bank and Fund, however, are liberal in other ways as well such as in their dedication to promoting accountability, transparency, good governance and the rule of law. Increasingly, the Bretton Woods institutions are focused on implementing these liberal principles.

Different aspects of the liberal tradition sometimes seem to conflict, as when the World Bank was called upon to deny loans to apartheid regimes by incorporating concern for human rights international into its lending decisions. Originally, the Bank argued that it could not do so without betraying its duty to act impartially and only on the basis of economic considerations rather than political ones. Later the Bank developed a more evolved view of its role as lender, under which it considers government human rights violations as an indicator of economic creditworthiness.

There was a parallel development with the consideration by the Bank of international environmental performance and standards. At first, the Bank view was that environmental considerations were merely a political consideration. More recently, the Bank has acknowledged that the adverse environmental effects of its lending projects can be understood in economic terms as "externalities" which are indeed part of the total cost.

37 This phrase, adapted from John Locke's Second Treatise on Government, was used by Thomas Jefferson in the US Declaration of Independence. See The Declaration of Independence, para. 2 (U.S. 1776). 


\section{III.D. Bretton Woods Voting and Decision-Making Procedures}

Voting and decision-making at the Bank and the Fund are organized along similar lines. The business of each is conducted by an Executive Board. The relative economic strength of the various member countries, and their contributions to the organization's resources, is reflected in the composition and voting of that Board. A "weighted voting" system is written into the treaties establishing Fund and Bank, ratifying and institutionalizing within them the inequality between the economically strong countries and the economically weak ones. As a result, the top five members wield $38 \%$ of the total voting power in the Fund ${ }^{38}$ and $37 \%$ in the World Bank. ${ }^{39}$ Together, the US and major European countries command more than $50 \%$ of voting power in each of them. The demand for greater equality has led the UN General Assembly to adopt resolutions calling for the reform of the decision-making procedures in international economic and financial institutions. ${ }^{40}$

Although apparently at odds with notions of "sovereign equality," ${ }^{41}$ the weighted voting procedure was a practical response to the valid concerns of major contributors about how the contributed funds would be used. Weighted voting answered these concerns and thereby assured the participation of donor countries.

Beyond the issue of weighted voting, the management structures of the Bretton Woods institutions are a direct affront to multiculturalism in another important way. According to an informal tradition, the post of IMF managing director is held by a European and the top job of the World Bank by an American. In practice these two appointment privileges have not been equally

38 The voting power percentages for each of the top five countries in the IMF is presently as follows: United States: $16.79 \%$, Japan: 6.02\%, Germany: 5.88\%, France: 4.86\%, and United Kingdom: 4.86\%. IMF website, http://www.imf.org/external/ $\mathrm{np} / \mathrm{sec} /$ memdir/eds.htm, consulted at 11:00 AM CST on June 15, 2007.

39 The percentages within the World Bank's principal organ, the International Bank for Reconstruction and Development (IBRD) are currently as follows -- United States: 16.41\%, Japan 7.87\%, Germany 4.49\%, France 4.31\%, United Kingdom: 4.31\%.

40 See, for example, Article 10 of the Charter of Economic Rights and Duties of States, adopted by the UN General Assembly as Resolution 3281 (XXIX) on 12 Dec. 1974.

41 Article 2 (1) of the UN Charter states that "The Organization is based on the principle of sovereign equality of all its Members". 
exercised.

In 2001 Europe's first proposed choice for IMF Managing Director was rejected, and essentially vetoed, by the US which then agreed to accept Europe's second choice. ${ }^{42}$ In contrast President George W. Bush's unilateral appointment of Paul Wolfowitz to head the World Bank in 2005 was effectively unilateral. Publicly known as a key architect of the disastrous US decision to invade Iraq in 2003, Wolfowitz was a controversial and divisive figure even within the US. He was a hated figure in Europe, ${ }^{43}$ but at the time of his confirmation European leaders unanimously supported his appointment as President of the World Bank. ${ }^{44}$ The US decision to nominate him was therefore accepted without any serious external review; as a US appointee his accountability came only after the fact when he was found to have violated Bank policies with regard to a staffer with whom he had a personal relationship. Once his improprieties were revealed he could not benefit from the reservoir of credibility and goodwill that would shore up a candidate with true international support.

The appointment of Wolfowitz, a polarizing ideological figure with little technical expertise in finance or development, as President of the World Bank was more likely to weaken the Bank's effectiveness than to reinforce it. ${ }^{45}$ Now,

42 The selection process of the IMF Managing Director in 2001 was described as follows: "Koehler's selection as managing director four years ago came after a power struggle among rich countries that was widely deplored as epitomizing the arbitrary nature of the process. Following the announcement in November 1999 by IMF Managing Director Michel Camdessus that he would retire, the German government made it clear that the time had come for a German to take the helm after two Frenchmen had held the job. Berlin's first nominee, Caio Koch-Weser, emerged as Europe's choice, but when the US government blocked his selection by the IMF board, German officials indignantly insisted on Koehler, then the head of the European Bank for Reconstruction and Development. Rather than risk a breach with the Germans, other nations acquiesced."

43 According to reports "[n]ews of Mr Wolfowitz's nomination was received with shock and awe by the international community." Comment \& Analysis: World Bank: Bush's elbow, not his ear, The Guardian (London), Final Edition, April 2, 2005, Gaurdian Leader Pages, 19.

44 Richard Bernstein, Is Europe Trying to Restore The Old Trans-Atlantic Club?, The New York Times, April 3, 2005, Section 1; Column 1; Foreign Desk; at 13.

45 The Italian business-oriented Il Sole 24 Ore, predicted that with Wolfowitz as president of the bank, "it will not be easy to 'sell' the World Bank as an institution that takes care of the poor in the world." As cited in Elaine Sciolino, Europe on Wolfowitz as Banker: Once Chilly, Now Tepid, The New York Times, March 31, 
after Wolfowitz's reluctant resignation, it is clear that the World Bank's efforts to promote transparency, good governance and the rule of law were undermined despite his sincere effort to promote development and his welcome focus on fighting against corruption.

The UN General Assembly has implored the Bretton Woods institutions to reform their decision-making protocols, but to no avail. Now over sixty years after the IMF and World Bank were established, it is time to reconsider the basic compromise on decision-making. This reform is necessary not only out of respect for multiculturalism, but also to promote accountability, practicality, the rule of law and the other liberal principles that are the basis of the Bretton Woods institutions.

The potential incompatibilities of the Bretton Woods institutions with the ideals of multiculturalism seem to dwarf those raised by the multicultural critique of the liberal state. It is legitimate to ask whether the Bank and Fund are fundamentally and irreparably instruments of a "hegemonic international law" 46 and antithetical to the multicultural ideal or at least impervious to it. I do not believe that they are.

My thesis is that the Bretton Woods institutions have the potential to become an arena within which different states, representing to some extent their peoples and cultures, "develop their identities together and in relation to each other via the same dialogical processes that are, for Taylor, at the very root of ethical substance and indispensable for recognition". 47 Although Western engineered and dominated, these institutions can accommodate multiculturalism insofar as they and the liberal principles they promote can adapt to remain sufficiently relevant to the multicultural psychology and politics of the $21^{\text {st }}$ century. There are clearly limits to how far liberal economic principles and Bretton Woods institutional structures can adapt, but a more complete understanding of them will only emerge gradually, aided by intercultural dialogue.

The same Bretton Woods practicality that developed weighted voting as a useful solution in the 1940s now requires a technical correction in response to the reality of multiculturalism and the power of the multicultural ideal in today's

2005, Section A; Column 3; Foreign Desk; at 12.

46 See below notes 72 to 81 and the associated text.

47 Brian Milstein, “On Charles Taylor's 'Politics of Recognition.”' Unpublished paper, New School for Social Research, New York (accessed on March 15, 2007 at 
world.

\section{Law, Politics and Multiculturalism at the Bank and Fund}

\section{IV.A. The Claim of the Bretton Woods Institutions to be Non-Political}

Both the Bank and Fund have always laid claim to a neutral, technocratic legitimacy. Article IV, section 10 of the World Bank's founding treaty is entitled "Political activity prohibited," and it sets out a clear rule that the Bank and its officers are not to be influenced by "the political character of the member or members concerned" and that "only economic considerations shall be relevant to their decisions." 48 This section has been interpreted as a prohibition on the politicization of the Bank.

The first part of Article IV(10) is clearly designed to protect member states from interference in their internal political affairs. The second part ${ }^{49}$ sets out a positive definition of how the Bank, its organs, and its officers are to exercise their discretion in decision-making. Both the General Counsel of the Bank, and the Bank's Executive Director's have endorsed the view that section 10 "is no more than a reflection of the technical and functional character of the Bank as it is established under its articles of agreement." 50

The IMF's charter does not contain language similar to Article IV(10) of

http://magictheatre.panopticweb.com/aesthetics/writings/polth-taylor.html).

48 Articles of Agreement of the International Bank for Reconstruction and Development, Article IV(10), reads as follows:

The Bank and its officers shall not interfere in the political affairs of any member; nor shall they be influenced in their decisions by the political character of the member or members concerned. Only economic considerations shall be relevant to their decisions, and these considerations shall be weighed impartially in order to achieve the purposes stated in Article I.

49 The second clause of that Article's first sentence mandates that the Bank and its officers shall not "be influenced in their decisions by the political character of the member or members concerned". This clause serves a dual purpose, providing some protection for the internal affairs of states while also setting out a "functionalist" definition of how the Bank is supposed to reach its decisions.

50 From a letter dated 5 May 1967 from the IBRD General Counsel to the UN Secretariat, cited in UNJY (1967), 121. 
the Bank's articles, ${ }^{51}$ but the Fund has nonetheless taken the position that it too is prohibited from making decisions based upon political considerations. ${ }^{52}$ In the Fund's official view, "[d]omestic policies are 'social' or 'political' if they do not fall within the scope of the purposes of the Fund as set forth in Article I, and the Fund may not base its decisions on political considerations of this character". ${ }^{53}$ Thus a political activity prohibition such as that explicitly set out in the Bank's charter technically applies to the Fund as well.

Although in principle both the Bank and Fund are to act solely on the basis of economic considerations, in practice this is more easily said than done. Both now consider the quality of a state's "governance" based on the argument that bad governance is economically relevant to lending decisions. This is not an exact science, however and even the Fund has conceded that "in practice there is seldom a clear separation between such economic and noneconomic aspects". ${ }^{54}$

This especially troublesome from a multicultural perspective because, in case of disagreement, the matter is resolved under the weighted voting system. The wealthy donor countries determine what is to be considered a technical economic matter and therefore relevant to the activities of these powerful organizations versus what is political and therefore in principle irrelevant. The injustice of this system threatens to undermine the credibility of the Bretton Woods institutions.

\section{IV.B. Past Attempts at Politicization of the World Bank}

The weighted voting systems of the IMF and World Bank are especially susceptible to politicization inasmuch as they concentrate so much influence in the hands of the US and a few allies. In a separate work the present author has

51 See Y. Yokota, Nonpolitical Character of the World Bank, Japanese Annual of International Law (1976), 45 ("For the Americans who [at Bretton Woods] held a view that economics cannot be separated from politics, it was perhaps easier to accept a non-political Bank than a non-political Fund").

52 See J. Gold, Political Considerations are Prohibited by Articles of Agreement when the Fund Considers Requests for Use of Resources, 12 IMF Survey (No. 10, 23 May 1983), 146.

53 Gold, n. 52 above, 146.

54 The Role of the IMF in Governance Issues: Guidance Note (Approved by the IMF Executive Board, July 25, 1997), para. 22. 
developed a legal approach to the issue of politicization in the law and practice of the World Bank. ${ }^{55}$ International organizations such as the Bank and Fund are established based on an agreement between their members to work to achieve common goals. A negotiated consensus on these goals, and on a set of rules and principles for achieving them, is then incorporated into a constitutive document in the form of a binding treaty. ${ }^{56}$ The use of such an organization's formal mechanisms for purposes other than those within the agreed consensus may violate its founding treaty and constitute an illegal act of politicization. ${ }^{57}$

Although every loan the Bank makes must be presented to the Executive Directors and formally approved by them, the decision on each proposal is actually made by consensus before it is formally presented. Any loan presented to the Executive Directors for a vote will normally be approved, and details of these loans are published by the Bank. The Bank publishes no statistics, however, about the loans which are discussed by the Executive Directors but not formally presented or approved. Without more information about these behind-thescenes discussions, it is impossible to do a systematic and comprehensive study of politicization in the Bank's decision-making.

The US Congress has often passed legislation requiring the US-appointed Executive Director not to support any proposed World Bank loans to a certain country, ${ }^{58}$ and often the rationale has been more political than economic. These Congressionally-mandated no votes have generally proved to be ineffective as a way to influence the Bank's lending decisions ${ }^{59}$ largely because the US does not have enough voting power in the Bank to block loans without the votes of other countries. In some cases, however, US politicization of the Bank may have been

55 See Bartram S. Brown, The United States and the Politicization of the World Bank: Issues of International Law and Policy (1992) at 234-253.

56 Id. at 17.

57 Id. at 27.

58 See, for example the Zimbabwe Democracy and Economic Recovery Act of 2001. Act Dec. 21, 2001, P.L. 107-99, 115 Stat. 962, 22 USC \2151, Sec. 4(c), requiring the US Executive Director to oppose or vote against proposed World Bank loans to Zimbabwe.

59 Two decades ago a survey of public records concluded that from October 1, 1979 to September 30, 1987, the US voted no 33 times and abstained 69 times on World Bank loans which were proposed to the Board of Executive Directors and that, astoundingly, every one of these 102 loan proposals was nonetheless approved by the Bank's Board. See, Brown supra note 55, at 253-255. 
effective in punishing the intended target. ${ }^{60}$ Even when unsuccessful, US efforts to politicize the Bank have undermined its reputation as a fair and non-political institution.

\section{IV.C. The IMF Role in the Asian Financial Crisis}

Beyond concerns about the fairness of decision-making procedures, the politicization of the Bretton Woods institutions, or the subjectivity of the economic issue versus political issue distinction, the Fund in particular has in recent years lost credibility as a competent economic advisor. The IMF's credibility problems began with the Asian Financial crisis of the 1990s but the Fund's greatest embarrassment came in its relations with Argentina subsequent to 2001 .

In 1997 a devastating financial crisis hit Thailand and spread quickly within the region to the Philippines, Indonesia, Malaysia and South Korea, and ultimately affected economies around the world. When the crisis began, the Fund formulated new programs for Thailand, Indonesia, and other affected Asian states, and these programs have been criticized for contributing to the panic in several ways. The IMF ordered sudden bank closures and, when these were implemented without a more comprehensive plan for financial sector reform, the effect was to deepen the panic. ${ }^{61}$ The Fund also contributed to the severe credit crunch by pushing banks to recapitalize within an unrealistic time frame and by recommending contractionary fiscal and monetary policies. ${ }^{62}$ Much of this advice was similar to past IMF prescriptions for debtor countries in the throes of overspending and inflation. Many doubt that this advice was an appropriate response to problems largely attributable to the volatility of private capital flows. ${ }^{63}$ In any case, the IMF's lending rose to record levels during the crisis. ${ }^{64}$

60 The denial of Bank loans to Czechoslovakia in the Bank's early years, and to Chile Between 1970 and 1973 when socialist Salvador Allende was in power are two examples. See, Brown supra note 55, at 132-135 and 164-178.

61 See IMF Now Admits Tactics in Indonesia Deepened Crisis, NY Times (14 Jan. 1998) at 1.

62 Summary of a July 1996 IMF Board discussion on Thailand, in Steven Radelet and Jeffrey Sachs, The Onset of the East Asian Financial Crisis (30 Mar. 1998) at 24-30.

63 See Paula Hawkins, International Misery Fund, The European (5 Oct. 1998), Section: Finance. 
The IMF has not publicly acknowledged making errors during the crisis, much less contributing to it. But there are reports that a confidential IMF review concluded that the Fund's policy on bank closures did indeed exacerbate the crisis. ${ }^{65}$ Despite the IMF's lack of official public contrition, several of its Directors have acknowledged that mistakes were made. The Fund reports without elaboration that some Directors expressed concern that Fund policies had liberalized capital movements before appropriate regulatory regimes were in place $^{66}$ or that the IMF had overreacted by loading the first stage of its programs with too many structural reforms. ${ }^{67}$

\section{IV.D. Argentina's Challenge to the IMF}

In 2001 Argentina was insolvent and had defaulted on its foreign debt. This is the typical situation in which a debtor country must turn to the IMF as the lender of last resort. The IMF can offer such a country a number of things, including financial resources to meet some of their immediate debts, advice on economic policy, and official IMF endorsement of their economic recovery plan. The IMF imprimatur is particularly valuable as it gives the green light to additional help from governments and private capital markets who rely on the IMF to act as de facto international financial policeman. But in order to receive it the borrower must sign a "letter of intent" signifying its agreement to implement the IMF's policy prescriptions.

Rather than accept the austerity and economic belt-tightening required by the IMF's draconian policy prescriptions, Argentina took another, more radical, approach. In 2005, after years of tension with creditors, Argentina bypassed the IMF in successfully renegotiating a $70 \%$ reduction of the bulk of its remaining foreign private debt. ${ }^{68}$ Argentina's President Nestor Kirchner has boasted that it

64 The total credits drawn from the IMF accounts during the years 1997/1998 reached a total of $\$ 75.4$ billion, $\$ 20.1$ billion more than the previous year. IMF Annual Report 1998, 13 (Overview-Asian Financial Crisis Propels IMF Activity to New Levels in 1997/98).

65 See IMF Now Admits Tactics in Indonesia Deepened Crisis, supra note 61 at 1.

66 See IMF Annual Report 1999, 36.

67 Id.

68 Larry Rohter, Argentina Announces Deal on Its Debt Default, The New York Times, March 4, 2005, Section C; Column 5; Business/Financial Desk; International 
was "the best debt renegotiation in history," 69 and it was all completed without the support of the IMF. In another damaging blow to the IMF's credibility, in 2006 Argentina finished paying back in full that country's \$US 10 Billion debt to the Fund.

Argentina still has substantial debt but has comfortable fiscal and current account surpluses adequate to deal with them. It has recently been attempting to normalize its relations with the Paris Club of officials from the world's richest countries. In the meantime Argentina has learned that, even without IMF or Paris Club support, it can still access international capital markets through local bond issues in Buenos Aires and bonds issued directly to Venezuelan banks eager to invest that country's oil surplus. ${ }^{70}$

This experience, however difficult it might be to replicate, ${ }^{71}$ has proven that an indebted state need not always accept the policy prescriptions of the IMF. The Fund's failure to acknowledge and address this new reality has undermined the credibility of the traditional Bretton Woods prescriptions.

\section{IV.E. Can the Bretton Woods Institutions Adapt?}

The World Bank has already demonstrated the capacity to adapt. In 1960 the Bank accepted the need to mitigate the severity of market based approaches when it created a new affiliate, the International Development Association or IDA. The IDA provides loans on concessional terms (i.e. charging no interest and with repayment terms up to 50 years) for the most impoverished borrower countries who are not eligible for its more market-based commercial financing. More recently the Bank has made important progress in incorporating human

Business; at 3.

69 Barrie McKenna, Argentina's joke on IMF has a bond issue punchline, The Globe and Mail (Canada), May 10, 2005, Section: Report on Business Column; World; at B13.

70 Benedict Mander, Argentina tries making peace Buenos Aires is offering to tackle its defaulted debt in a bid to boost foreign investment, Financial Times (London, England), December 15, 2006, Section: Capital Markets And Commodities; at 39.

71 Argentine relied on financial assistance from Venezuela which, under the leadership of IMF critic President Hugo Chavez, has invested oil revenue in US \$billions worth of otherwise difficult to market Argentine bonds. The unusually favorable market conditions may also have played a role. Future debtors may not benefit from these favorable circumstances. 
rights and environmental concerns into its decision-making.

In contrast, the IMF has done relatively little to adapt to changing circumstances, although it has made some effort. In 1999 the IMF's Executive Board authorized gold sales by the IMF to generate the equivalent of about US $\$ 3$ billion to help finance the IMF's contribution to debt relief and financial support for the world's poorest nations. Since the Fund, unlike the bank, is not a development institution, this policy takes the Fund beyond its original mission.

\section{IV.F. The Choice: Multiculturalism or Hegemonic International Law?}

China is rising fast, but the US is still the predominant military and economic power in the world today. There is concern about this fact even among US allies. ${ }^{72}$ One danger is that international law and multilateral institutions could become just another tool used by the hegemonic power to enforce its dominance.

Detlev Vagts, noting that the United States is increasingly referred to "as the hegemonic (or indispensable, dominant, or preeminent power), ${ }^{73}$ has suggested that a distorted hegemonic international law ${ }^{74}$ might result from this

72 Former French Foreign Minister Hubert Vedrine once described the United States as a "hyperpower . . . a country that is dominant or predominant in all categories." He suggested that this domination could best be resisted "[t]hrough steady and persevering work in favor of real multilateralism against unilateralism, for balanced multipolarism against unipolarism, for cultural diversity against uniformity." Quoted in, To Paris, U.S. Looks Like a 'Hyperpower', International Herald Tribune, February 5, 1999 at 5.

73 Detlev F. Vagts, Hegemonic International Law, 95 Am. J. Int’l. L. 843, 843 (2001).

74 Jose E. Alvarez, Hegemonic International Law Revisited, 97 Am. J. Int'l L. 873, 873 (2003):

HIL jettisons or severely undervalues the formal and de facto equality of states, replacing pacts between equals grounded in reciprocity, with patron-client relationships in which clients pledge loyalty to the hegemon in exchange for security or economic sustenance. The hegemon promotes, by word and deed, new rules of law, both treaty based and customary. It is generally averse to limiting its scope of action via treaty; avoids being constrained by those treaties to which it has adhered; and disregards, when inconvenient, customary international law, confident that its breach will be hailed as a new rule. Substantively, HIL is characterized by indeterminate rules-whose vagueness benefits primarily (if not solely) the hegemon-recurrent projections of military 
dominance. As he describes it, hegemonic international law downplays the idea of the equality of states. ${ }^{75}$ Instead, the hegemonic power uses ambiguous or indeterminate treaty language to claim greater freedom to impose its own preferred interpretation of applicable rules. ${ }^{76}$ In particular, Hegemonic International Law is characterized by the hegemon's circumvention of the basic rule against military intervention in the internal affairs of other states. ${ }^{77}$

Vagts has questioned whether the US has the political and psychological infrastructure to act as a true hegemon. ${ }^{78}$ Jose Alvarez has discussed the possibility of "hegemonic capture of the Security Council" 79 but what about the Hegemonic capture of the World Bank and IMF? Even with only $28 \%$ of the total voting power, the US has more control over the Bank and Fund than it does over the UN Security Council where decisions are subject to veto by Russia, China, France or even the UK. Those who believe that international law is not really law ${ }^{80}$ or who believe that the US should be unapologetic about using its

force, and interventions in the internal affairs of other nations.

75 See Vagts, supra note 73 at 845 ("The received body of international law is based on the idea of the equality of states .... To get to HIL, one must discard or seriously modify this principle.").

76 See Vagts, supra note 73 at 846.

77 See Vagts, supra note 73 at 845 ("A shift to HIL most specially requires setting aside the norm of nonintervention into the internal affairs of states.").

78 See Vagts, supra note 73 at $844-45$ (according to Vagts, doubts remain about the US as hegemon:

The terrible blows of September 11, 2001, raise the question whether the United States can or will act as a hegemon in a drastic way, that is, in Krauthammer's terms, whether it can carry out "unapologetic and implacable demonstrations of will." .. . Nor does the United States have the political and psychological infrastructure hegemony calls for. Thus, the jury is still out on whether we will be a hegemon ....)

79 See Alvarez, supra note 138 at 873-74 (arguing that "despite that body's refusal to give explicit approval to Operation Iraqi Freedom in advance, worries about the hegemonic capture of the Security Council (along with other forms of global HIL) should not be relegated to science fiction. At the same time, it should be understood that global HIL, like other forms of hegemony, is a Janus-faced phenomenon, capable of winning praise or condemnation from all points on the political spectrum").

80 See, John R. Bolton, Is There Really "Law" in International Affairs? 10 Transnat'l L. \& Contemp. Probs. 1, 48 (2000). 
singular power to reshape international norms ${ }^{81}$ would presumably welcome the extension of US hegemony through the decisions of the Bretton Woods institutions.

But from a multicultural perspective, hegemonic international law is completely unacceptable. The hegemony of any one country or cultural group denies recognition to others and is therefore incompatible with the values of multiculturalism. If the perception persists that the Bank and/or Fund are instruments of hegemonic international law, the ultimate cost, potentially to be borne by the US as by others is that this will reduce and perhaps destroy the future utility of these institutions to states and to the international community as a whole.

\section{Conclusions}

\section{V.A. Politicization and Consensus}

The utility and continued viability of the Bretton Woods institutions depends upon three different types of consensus. First, there is the political consensus on the goals to be achieved. The consensus goal of the Fund is to promote international monetary stability and that of the Bank is to promote international economic development. For the most part these political goals are not in question.

Also essential, although more elusive, is a technical consensus on the best and most appropriate means to achieve those objectives. Within the Bretton Woods organizations, the technical consensus has always been dominated by economists. Following the Asian financial crisis in the late 1990s and Argentina's apparently successful debt restructuring on its own terms, the IMF technical consensus is now very much in question. Even if fundamental changes are to be made, parts of the Bretton Woods technical consensus will need to be preserved. As the Bank and Fund incorporate lessons from multicultural dialogue and experience they will need to maintain a pragmatic, functional methodology.

81 Charles Krauthammer, The Bush Doctrine in American foreign policy, A New Motto: Don't Ask, Don’t Tell, TIME, Mar. 5, 2001 at 42. “America is no mere international citizen. It is the dominant power in the world, more dominant than any since Rome. Accordingly, America is in a position to reshape norms, alter expectations and create new realities. How? By unapologetic and implacable demonstrations of will." 
Lastly, effective international economic cooperation depends upon a normative consensus which cannot be built or maintained without a foundation in multiculturalism. The requirement of opinion juris in the development of rules of customary international law means that new rules must be supported by a broad multilateral, and therefore multicultural, consensus. Any new rules for the Bretton Woods institutions must also be built on that basis.

\section{V.B. The Bretton Woods Institutions Must Adapt}

After their recent embarrassments both the World Bank and the IMF should recognize as never before the value of and need for a multicultural perspective. The ill-fated appointment of Paul Wolfowitz as President of the World Bank has exposed the US Government's abuse of its dominance within that institution. There will no doubt be consequences. In the future any US nominee for World Bank President will draw much greater scrutiny from the international community, which is only appropriate for such a key international post. Meanwhile the IMF's prescriptions for economic adjustment have lost their luster, and accepting the Fund's advice is no longer the only option for internationally indebted states. The Fund now needs to make adjustments of its own.

The IMF and World Bank have not always advanced multicultural identities, interests and values, but those institutions can still provide a way forward consistent with multiculturalism. In fact, they may be needed more than ever in the future. Only certain policies and principles often associated with liberalism can reconcile the multicultural perspective with both human rights and the practical legal framework essential to the rule of law. International financial institutions can preserve the best of liberal tradition by incorporating the multicultural perspective into that tradition.

To remain relevant and effective, the Bretton Woods Institutions must avoid two opposing ideological extremes. On the one hand, would be the ethnocentric notion that the Bretton Woods institutions, and the Western powers who fashioned them, can have nothing to learn from the rest of the world. ${ }^{82}$ For obvious reasons this attitude is seen as both arrogant and insulting

82 US Supreme Court Justice Antonin Scalia, in the course of a dissenting opinion by that august body, wrote that the majority's citation of foreign law was not only 
by much of the world. The peril at the other extreme is of a crude cultural relativism which could undercut achievements in the development of internationally recognized human rights standards since the 1940s.

\section{V.C. A Human Rights Perspective}

Multiculturalism should not be confused with ethical relativism. The notion that all cultural conceptions, values, and principles are relative is extreme, and clearly incompatible with internationally recognized human rights. An openness to different cultural perspectives is generally a good thing, but it cannot justify violations of human rights or any other norms of jus cogens.

Western governments, and the US Government in particular, have often been tempted to take a narrowly liberal approach to human rights and economic development. The Anglo-American liberal perspective tends to prioritize civil and political rights over economic, social and cultural rights. ${ }^{83}$ But the Bretton Woods institutions cannot thrive by stressing civil and political rights and free market economic principles to the complete detriment of economic, social and cultural rights. One important lesson learned in inter-cultural dialogue is that maintaining and advancing the international consensus on human rights requires a holistic approach. ${ }^{84}$ Only within the framework of interdependent and indivisible human rights can both multiculturalism and the liberal goals of the Bank and Fund be fully realized.

"meaningless dicta," but also "dangerous" since as he put it "this Court ... should not impose foreign moods, fads, or fashions on Americans." Lawrence v. Texas 539 U.S. 558, 598 (2003). Cf. also, Bhikhu Parekh, Rethinking Multiculturalism: Cultural Diversity and Political Theory (2000), describing the position of so-called "moral monists" at 16,216 , and 149 .

83 "Those who take the view that individual rights must always come first, and, along with nondiscrimination provisions, must take precedence over collective goals, are often speaking from a liberal perspective that has become more and more widespread in the Anglo-American world. Its source is, of course, the United States, and it has recently been elaborated and defended by some of the best philosophical and legal minds in that society including John Rawls, Ronald Dworkin, Bruce Ackerman, and others." The Politics of Recognition, supra note 6 at 56 .

84 See, the Vienna Declaration, World Conference on Human Rights, Vienna, 14 - 25 June 1993, U.N. Doc. A/CONF.157/24 (Part I) at 20 (1993) at para. 5, noting that 


\section{V.D. Liberalism's Capacity to Adapt to Multiculturalism}

Despite the apparent contradiction between liberalism's politics of equal dignity and multiculturalism's politics of the recognition of difference, the two are not antithetical. Far from being an unchanging set of dogma, the liberal tradition has long appreciated the need for dialectic advancement and development. Multiculturalism flows logically from liberalism's norms of equal dignity ${ }^{85}$ and in the past few decades multiculturalism has become an important current in contemporary liberal thought.

Marx predicted that capitalism would inevitably lead to revolution and communism. For the most part this did not happen, in part because liberalism, which borrowed and incorporated elements of capitalism, also helped that capitalism to develop into something more durable, viable and more potentially useful and of universal value. Liberal state trade unions, among other innovations, have helped mitigate the extremes of laisse-faire capitalism. Comparable adaptations are now needed if the productive potential of the liberal economic order is to be preserved in a multicultural world. Neither the pace of that reform nor its ultimate success, can be reliably predicted at this time, but this goal can be accomplished if supported by enlightened leadership from a multicultural alliance including liberal states.

"[a]11 human rights are universal, indivisible and interdependent and interrelated".

85 The Politics of Recognition, supra note 6 at 68. 